Journal of Advanced Research in Applied Sciences and Engineering Technology

Journal homepage: www.akademiabaru.com/araset.html ISSN: 2462-1943

\title{
Sustainable Green Concrete by using Biomass Aggregate
}

\author{
Tang Hing Kwong ${ }^{1,}{ }^{*}$, Flora Anak Albert Daud ${ }^{1}$, Chai Teck Jung ${ }^{2}$ \\ Department of Civil Engineering, Politeknik Kuching Sarawak, KM 22, Jalan Matang, 93050, Kuching Sarawak, Malaysia \\ Jabatan Pendidikan Politeknik dan Kolej Komuniti, Aras 5-7, Jalan P4W, Persiaran Perdana, Presint 4, 62100 Putrajaya, Malaysia
}

\begin{abstract}
The use of concrete for construction had become very common in developing countries. But concrete is not friendly environment because of it consumes huge quantities of natural materials and production of the cement, which is a major contributor to greenhouse gas emissions and global warming. The aim of this study is to investigate the Sustainable Green Concrete (SGC) which containing biomass aggregate; fly ash and Superplasticizer. Biomass aggregate and fly ash are waste industry products which are environmentally friendly. The study was carried out to identify the chemical properties of biomass aggregate, and to determine the chemical properties and optimum mix design of the Sustainable Green Concrete (SGC). A total of 90 cube samples were casted and compressive strength were tested at the age of 7, 14 and 28 days. The overall results showed that the workability and compressive strength were decreased with the increase of the replacement of natural aggregate with biomass aggregate. Besides that, the workability and compressive strength was increased with the incorporation with the replacement cement by fly ash. The SGC gained highest compressive strength for the concrete mixes of $39.3 \mathrm{~N} / \mathrm{mm}^{2}$ with the optimum percentage used of SGC in producing concrete not exceeding $30 \%$ biomass aggregate and $6 \%$ of fly ash as a partial replacement with natural aggregate and cement respectively. The results obtained and observation made in this study suggested that biomass aggregate and fly ash are successfully used as partial replacement in producing SGC and can perform better strength development.
\end{abstract}

\section{Keywords:}

Sustainable Green Concrete (SGC);

Biomass Aggregate (BA); Fly Ash (FA);

compressive strength; workability

Copyright @ 2020 PENERBIT AKADEMIA BARU - All rights reserved

\section{Introduction}

Based on Valeria et al. [1] Pravin et al.,[2], traditionally the Concrete industry has been considered a major producer of Greenhouse gas (GHG) emissions, mainly due to the high environmental footprint of cement. Based on the Desai et al., [3], the use of supplementary cementitious material (SCM) such as fly ash, blast furnace slag, silica fume and biomass aggregate from waste material has been widely used for the application and development sustainable concrete or green concrete. The common SCMs studied included, but may not be limited to fly ash, furnace slag, and silica fume [46]. Other researchers have also investigated some alternative aggregates (AA), such as building rubbles, oyster shell, recycled concrete aggregate (RCA), and waste-expended polystyrene reground material [7-10]. Based on the research conducted by Mark et al., [11] structural and durability test

\footnotetext{
${ }^{*}$ Corresponding author. tanghingkwog@gmail.com
}

https://doi.org/10.37934/araset.18.1.3137 
showed that High Performance Cement (HPC) containing fly ash and $50 \%$ recycled aggregate performed equally or better than $100 \%$ ordinary portland cement concrete with the same cementitious content [11]. But based on Limbachiya et al., [12] concluded that $30 \%$ of Recycled Concrete Aggregate (RCA) replacement decreased concrete strengths [12]. However, sustainable green concrete studies were hardly available in Malaysia. Based on Lepech et al., [13] to achieve high strength in the Sustainable Green Concrete, the use of supplementary cementitious materials (SCMs), recycled aggregates and other industrial wastes are encouraged.

\section{Methodology}

The raw materials for this study are Ordinary Portland Cement (OPC) with class strength 42.5, natural fine aggregates and granite, biomass aggregate, fly ash, superplasticizer (Supracoat SP800) and water. The biomass aggregate used is burning plywood waste which was obtained from LingShanhao Plywood Sdn Bhd, WTK Holdings located at Demak Laut Free Industrial Zone, Kuching, Sarawak as shown in Figure 1. The fly ash used is coal waste from Sejingkat Power Corporation Sdn. Bhd. Kuching which was obtained from Gobel Industry Sdn. Bhd. located at Jalan Bako, Kuching Sarawak. The maximum size of natural fine aggregates comply with BS EN 12620 is 4.75mm [14] which passed through the sieve analysis conducted.

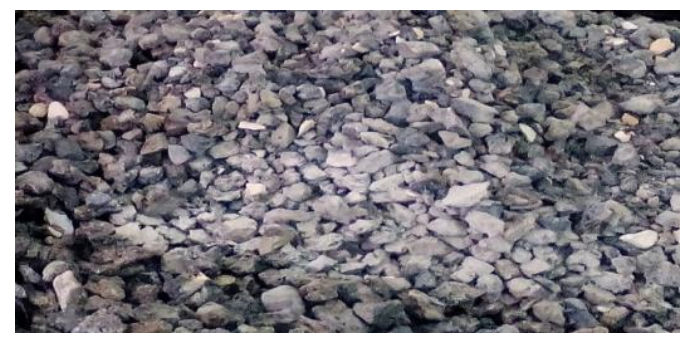

Fig. 1. Biomass aggregate from waste burning plywood

The determination of chemical composition of biomass aggregate will be done by using Standardless Method of X-Ray Fluorescence (XRF) test. Bulk density test of fine aggregates and granite will be conducted. The aggregate impact value (AIV) test is carried out to access the suitability of aggregate as regards the toughness for use in construction work. The aggregate impact value was expressed by Eq. 1 and compared with the strength characteristic of Aggregate Impact Value (AIV) as in BS812: 112: 1990.

$A I V=\underline{\text { Weight of the portion of crushed material passing } 2.36 \mathrm{~mm} \text { sieve, } W_{2}(\mathrm{~g}) \times 100 \%}$

Total weight of dry sample, $\mathrm{W}_{1}(\mathrm{~g})$

The aggregate crushing value (ACV) is an indirect measurement to determine the crushing strength of the aggregates [15]. The aggregate crushing value was expressed by Eq. 2 as below:

\section{$A C V=$ Weight of the portion of crushed material passing $2.36 \mathrm{~mm}$ sieve, $\mathrm{W}_{2}(\mathrm{~g}) \times 100 \%$}

Total weight of dry sample, W1 (g)

The workability of fresh SGC was measured to the nearest $5 \mathrm{~mm}$ using the ruler and the results is valid if it yields a true slump, this being a slump in which the concrete remains substantially intact and symmetrical according to BS 1881: Part 102: 2013 [16]. The SGC dry density will be recorded after 
28 days curing before conducting the compressive strength to determine the weight changing compared with control specimens.

The compressive strength was carried out at the age of 7, 14 and 28 days of water curing and subjected to the maximum compression axial loads applied. In term to obtain the compressive strength, it can be calculated by using Eq. 3 according to BS 1881: Part 116: 1983 [17].

$$
\text { Compressive Strength, } \sigma=\frac{\text { Max. Axial Load Applied }(\mathrm{N})}{\text { Cube Cross-Sectional Area }\left(\mathrm{mm}^{2}\right)}
$$

There were SIX (6) series of concrete mix which consist of Biomass Aggregate (BA) and Fly Ash (FA). There were SIX (6) categories of concrete mixes and a total of Ninety $150 \times 150 \times 150 \mathrm{~mm}$ cubes specimens were prepared to determine the concrete compressive strength. The mix proportions for the present study are tabulated in Table 1.

Table 1

Concrete Mix Design for Sustainable Green Concrete

\begin{tabular}{cccccc}
\hline $\begin{array}{c}\text { Batches/ } \\
\text { Series }\end{array}$ & $\begin{array}{c}\text { Water/ cement } \\
\text { Ratio }\end{array}$ & $\begin{array}{c}\text { Biomass } \\
\text { Aggregate (\%) }\end{array}$ & $\begin{array}{c}\text { Fly Ash } \\
\text { (FA) (\%) }\end{array}$ & $\begin{array}{c}\text { Cement } \\
(\%)\end{array}$ & $\begin{array}{c}\text { Natural } \\
\text { Aggregate (\%) }\end{array}$ \\
\hline A & 0.35 & 0 & 0 & 22 & 78 \\
B1 & 0.35 & 15 & 0 & 22 & 63 \\
B2 & 0.35 & 30 & 0 & 22 & 48 \\
C1 & 0.35 & 30 & 4 & 18 & 48 \\
C2 & 0.35 & 30 & 6 & 16 & 48 \\
C3 & 0.35 & 30 & 8 & 14 & 48 \\
\hline
\end{tabular}

Source: Concrete Mix Design from SCIB Concrete Manufacturing Sdn Bhd, Junda Realty Sdn Bhd, Kuching \& Cemex

1) Dosage of Suprachem SP800 per $100 \mathrm{~kg}$ of cement $(K G)=0.60$

2) Type of coarse aggregate: Granite

\section{Results}

\subsection{Properties of Raw Materials}

The mass and bulks densities of cement, fly ash, natural fine aggregate, granite and biomass aggregate are summarized in Table 2 . The result showed the compacted bulk density with high increasing with biomass aggregate which are $26.15 \%$ after the compaction by using steel rod in the cylinder steel mould. According to the Suraya, H. A. et al., the result indicated biomass aggregate contain porous particles which are breakable but there was ability to enhance the concrete water permeability if compare to granite [18].

Table 2

Mass Properties of Raw Materials

\begin{tabular}{lccc}
\hline \multicolumn{1}{c}{ Materials } & $\begin{array}{c}\text { Loose Bulk Density } \\
\left(\mathrm{kg} / \mathrm{m}^{3}\right)\end{array}$ & $\begin{array}{c}\text { Compacted Bulk } \\
\text { Density }\left(\mathrm{kg} / \mathrm{m}^{3}\right)\end{array}$ & $\begin{array}{c}\text { Loose Versus } \\
\text { Compacted (\%) }\end{array}$ \\
\hline Cement & 929.55 & - & - \\
Fly Ash & 909.34 & - & - \\
Natural Fine Sand & 1212.45 & 1333.70 & $9.09 \%$ \\
Granite & 1010.38 & 1293.28 & $21.88 \%$ \\
Biomass Aggregate & 969.96 & 1313.49 & $26.15 \%$ \\
\hline
\end{tabular}




\subsection{Chemical Composition for Biomass Aggregate}

The results in Table 3 showed that biomass aggregate contain $65.30 \%$ of Silicon Dioxide (SiO2) which has similar chemical properties of cement and silica fume. According to [19], silica fume which has a higher surface area and higher Silicon Dioxide (SiO2) content will help to increase the strength development of the concrete itself through reactivity to the rate of hydration fraction of the cement in the first instance.

Table 3

Chemical Compound of Biomass Aggregate

\begin{tabular}{lcc}
\hline \multicolumn{1}{c}{ Chemical Name } & Formula & Concentration (\%) \\
\hline Orig & $\mathrm{g}$ & 8 \\
Added & $\mathrm{g}$ & 2 \\
Carbon dioxide & $\mathrm{CO}_{2}$ & 0.10 \\
Silicon dioxide & $\mathrm{SiO}_{2}$ & 65.30 \\
Calcium oxide & $\mathrm{CaO}$ & 0.63 \\
Chloride & $\mathrm{Cl}$ & 1.41 \\
Aluminium oxide & $\mathrm{Al}_{2} \mathrm{O}_{3}$ & 15.50 \\
Sodium oxide & $\mathrm{Na}_{2} \mathrm{O}$ & 1.44 \\
Iron oxide & $\mathrm{Fe}_{2} \mathrm{O}_{3}$ & 5.12 \\
Magnesium oxide & $\mathrm{MgO}$ & 0.66 \\
Potassium oxide & $\mathrm{K}_{2} \mathrm{O}$ & 5.68 \\
Sulfur Trioxide & $\mathrm{SO}_{3}$ & 1.17 \\
Titanium oxide & $\mathrm{TiO}_{2}$ & 1.37 \\
Phosphoros & $\mathrm{P}$ & $0<\mathrm{LLD}$ \\
\hline
\end{tabular}

Note:*Using Standard less method, measured from Na to $U$ (refer to periodic table)

** $1 \%=10,000 \mathrm{ppm}$

\subsection{Aggregate Crushing Value (ACV) \& Aggregate Impact Value (AIV) for Biomass Aggregate}

The experimental result in Table 4 obtained showed that the ACV value for biomass aggregate was $29.0 \%$ while AIV value was $26.5 \%$. According to BS 882 : 1992 , biomass aggregate can be classified as good material or enough stronger to use for the concrete mix because their crushing value of $29.0 \%$ is lower to the limit value which there have enough ability to resist crushing [20]. Besides that, the AIV test showed that the aggregate not significant affected by the impact load which is $26.5 \%$ only. According to BS 882, biomass aggregate can be classified normal strength used for concrete.

Table 4

Aggregate Crushing Value (ACV) \& Aggregate Impact Value (AIV) for the Biomass Aggregate

\begin{tabular}{|c|c|c|}
\hline \multicolumn{2}{|c|}{ Physical Properties Biomass Aggregate } & BS 882:1992 \\
\hline $\begin{array}{c}\text { Aggregate Crushing } \\
\text { Value }(A C V) \%\end{array}$ & $\begin{array}{c}\text { Aggregate Impact } \\
\text { Value (AIV) \% }\end{array}$ & $\begin{array}{c}\text { Classification } \\
\text { (Not exceeding \%) }\end{array}$ \\
\hline 29.0 & 26.5 & $\begin{array}{l}<25 \text { (Heavy duty concrete floor) } \\
<30 \text { (Pavement wearing surfaces) } \\
50 \text { (Others) }\end{array}$ \\
\hline
\end{tabular}




\subsection{Workability for Sustainable Green Concrete}

Based on Figure 2, the slump value decreases occurred due to the increase of biomass aggregate as partial replacement for granite because this type of aggregate is produced from combustion process which consumes more water for the reaction as Pozzolanic materials. The results also showed that fly ash added will increase the concrete slump because the fly ash will react as a water reducer which is important to improve the workability, rheological properties of fresh concrete and ultimate strength as well as durability of hardened concrete [21].

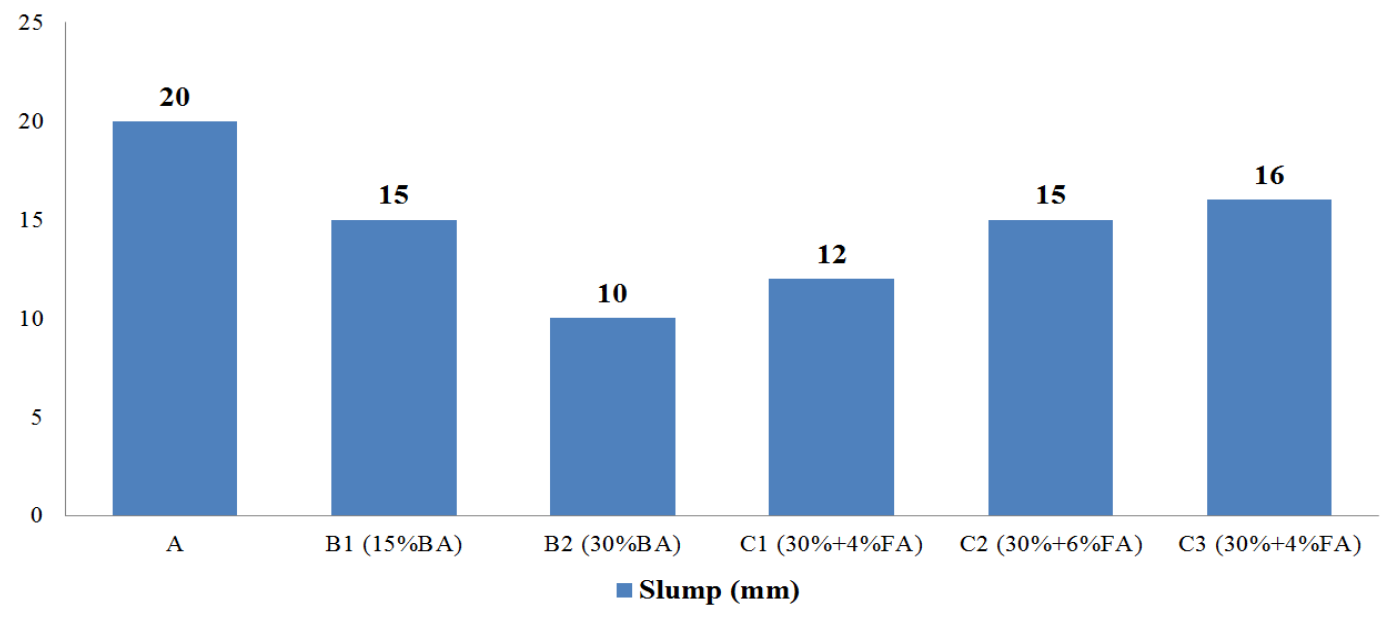

Fig. 2. Sustainable Green Concrete Slump

\subsection{Compressive Strength for Sustainable Green Concrete}

The data in Table 5 presented that the compressive strength of concretes mixes with biomass aggregate (Series B1 \& B2) was lower than that of control/ original mix (Series A). In this study, it was found that the use of $30 \%$ biomass aggregate in conjunction with $6 \%$ fly ash achieved higher compressive strength of $39.3 \mathrm{~N} / \mathrm{mm}^{2}$.

Table 5

Compressive Strength for Sustainable Green Concrete

\begin{tabular}{ccccl}
\hline Batches/ & \multicolumn{2}{c}{ Average Compressive Strength, $\sigma=\mathrm{P} / \mathrm{A}\left(\mathrm{N} / \mathrm{mm}^{2}\right)$} & \multirow{2}{*}{ Concrete Mix } \\
\cline { 2 - 4 } Series & 7 days & 14 days & 28 days & \\
\cline { 1 - 4 } A & 25.2 & 32 & 35.1 & Original \\
B1 & 23.7 & 29 & 34.4 & $15 \%$ BA \\
B2 & 21.6 & 23 & 29.1 & $30 \%$ BA \\
C1 & 21.5 & 27 & 32.0 & $30 \%$ BA + 4\% FA \\
C2 & 25.7 & 33 & 39.3 & $30 \%$ BA + 6\% FA \\
C3 & 23.2 & 29 & 33.6 & $30 \%$ BA + 8\% FA \\
\hline
\end{tabular}

\subsection{Statistic Analysis for the Compressive Strength}

Based on the results obtained in Table 6, the standard deviation of the compressive strength for the all SIX (6) series concrete mixes will be considerably low standard deviation means with standard deviation range between 1.60 to 4.74 which the data are tightly clustered or scattered around the mean; the concrete mixes with biomass aggregate and fly ash are smaller variability than the control at 28 days for the compressive strength which has high standard deviation means that they are widely 
scattered for control/ original concrete mixes. The COV results obtained also showed that the confident of the data collected and the quality of experimental work done was in good condition.

Table 6

Mean samples, standard deviation and coefficient of variance for the compressive strength

\begin{tabular}{|c|c|c|c|c|c|c|c|c|c|}
\hline \multicolumn{3}{|c|}{ Mean } & \multicolumn{3}{|c|}{$\begin{array}{l}\text { Standard } \\
\text { Deviation }\end{array}$} & \multicolumn{3}{|c|}{$\begin{array}{c}\text { Coefficient of } \\
\text { Variance (COV) \% }\end{array}$} & \multirow[t]{3}{*}{ Note } \\
\hline 7 & 14 & 28 & 7 & 14 & 28 & 7 & 14 & 28 & \\
\hline Days & Days & Days & Days & Days & Days & Days & Days & Days & \\
\hline 25.24 & 31.56 & 35.11 & 0.96 & 0.87 & 4.74 & 3.82 & 2.76 & 13.49 & Ori \\
\hline 23.73 & 0 & 3 & 1.86 & 1.12 & 3.69 & 7.85 & 3.86 & 10.72 & \\
\hline 21.60 & 2.67 & 29.07 & 2.05 & 2.01 & 1.60 & 9.50 & 8.88 & 5.51 & 30 \\
\hline 21 & 6 & 3 & 2.10 & 2.00 & 2.14 & 9.76 & 7.5 & 6.68 & $30 \%$ \\
\hline 25.73 & .07 & 39.29 & 3.87 & 3.60 & 3.41 & 15.05 & 10.88 & 8.67 & $30 \%$ \\
\hline 23.20 & 29.16 & 33.60 & 1.74 & 1.74 & 1.60 & 7.50 & 5.97 & 4.75 & $30 \% \mathrm{BA}+8 \% \mathrm{FA}$ \\
\hline
\end{tabular}

\section{Conclusions}

Based on the findings of this study, all the experimental data shows that the replacement of the biomass aggregate will decrease concrete strength but the replacement of the fly ash will improve the concrete properties. This is because the chemical compositions of biomass aggregate consist $65.3 \%$ Silicon Dioxide (SiO2) will create the pozzolanic reaction with the calcium hydroxide $(\mathrm{Ca}(\mathrm{OH}) 2)$ or lime in Portland cement. But in SGC development, this pozzolanic reaction does not help to increase the strength development of the concrete itself because of the water adsorption by biomass aggregate will affect the workability and compaction in the concrete mixes. However, the replacement of fly ash to concrete is able to provide as high improvement levels which shown in the replacement of granite with $30 \%$ biomass aggregate and $6 \%$ fly ash gives an excellent result in strength and quality aspects. Finally, the compressive strength results also indicated that the optimum percentage used for SGC as partial replacement in producing concrete was $30 \%$ biomass aggregate plus $6 \%$ fly ash. It can be seen that the compressive strength for the concrete mixes Series C2 performed the highest compressive strength at the age of 28 days which were $39.3 \mathrm{~N} / \mathrm{mm}^{2}$ while others of percentage replacement showed the decrease for compressive strength. These results are of great importance because this kind of innovative concrete requires large amounts of fine particles. From the above study, it is concluded that the biomass aggregate and fly ash can be used as a replacement material for coarse aggregate and cement in the concrete mixes. The following recommendations may be made based on the conclusions from this study such as further tests with longer curing ages such as 60 and 90 days should be investigated.

\section{Acknowledgement}

We would like to acknowledge the support from our organisations: Politeknik Kuching Sarawak \& School of Education, UTM. However, the contents of this work are solely the responsibility of the authors.

\section{References}

[1] Corinaldesi, Valeria, Giacomo Moriconi, and Tarun R. Naik. "Characterization of marble powder for its use in mortar and concrete." Construction and building materials 24, no. 1 (2010): 113-117.

https://doi.org/10.1016/i.conbuildmat.2009.08.013

[2] Kumar, Praveen, and S. K. Kaushik. "SCC with crusher dust, fly ash and micro-silica." Indian concrete journal 79, no. 8 (2005): 33-37. 
[3] Desai, D.B., Gupta, A.K., and Pradeep K. (2013). “Green Concrete: Need of Environment." International Journal of Advanced Science, Engineering and Technology, 2(2) (pp. 134-137).

[4] Basri, H. B., M. A. Mannan, and Muhammad Fauzi Mohd Zain. "Concrete using waste oil palm shells as aggregate." Cement and concrete Research 29, no. 4 (1999): 619-622.

https://doi.org/10.1016/S0008-8846(98)00233-6

[5] Kevern, John T., Vernon R. Schaefer, and Kejin Wang. "Mixture proportion development and performance evaluation of pervious concrete for overlay applications." ACI Materials Journal 108, no. 4 (2011): 439.

https://doi.org/10.14359/51683117

[6] Limbachiya, Mukesh, Mohammed Seddik Meddah, and Youssef Ouchagour. "Performance of Portland/Silica Fume Cement Concrete Produced with Recycled Concrete Aggregate." ACl Materials Journal 109, no. 1 (2012).

https://doi.org/10.14359/51683574

[7] Khalaf, Fouad M., and Alan S. DeVenny. "Recycling of demolished masonry rubble as coarse aggregate in concrete." Journal of materials in civil engineering 16, no. 4 (2004): 331-340. https://doi.org/10.1061/(ASCE)0899-1561(2004)16:4(331)

[8] Yang, Eun-Ik, Seong-Tae Yi, and Young-Moon Leem. "Effect of oyster shell substituted for fine aggregate on concrete characteristics: Part I. Fundamental properties." Cement and Concrete Research 35, no. 11 (2005): 2175-2182. https://doi.org/10.1016/i.cemconres.2005.03.016

[9] Berry, Michael, Jerry Stephens, and Doug Cross. "Performance of $100 \%$ fly ash concrete with recycled glass aggregate." ACI Materials Journal 108, no. 4 (2011): 378. https://doi.org/10.14359/51683110

[10] Trussoni, Matthew, Carol D. Hays, and Ronald F. Zollo. "Comparing Lightweight Polystyrene Concrete Using Engineered or Waste Materials." ACl Materials Journal 109, no. 1 (2012). https://doi.org/10.14359/51683575

[11] Reiner, Mark, Stephan A. Durham, and Kevin L. Rens. "Development and analysis of high-performance green concrete in the urban infrastructure." International Journal of Sustainable Engineering 3, no. 3 (2010): 198-210. https://doi.org/10.1080/19397031003746662

[12] Limbachiya, Mukesh, Mohammed Seddik Meddah, and Youssef Ouchagour. "Performance of Portland/Silica Fume Cement Concrete Produced with Recycled Concrete Aggregate." ACI Materials Journal 109, no. 1 (2012). https://doi.org/10.14359/51683574

[13] Lepech, Michael D., Victor C. Li, Richard E. Robertson, and Gregory A. Keoleian. "Design of green engineered cementitious composites for improved sustainability." ACl Materials Journal 105, no. 6 (2008): 567. https://doi.org/10.14359/20198

[14] BS EN 12620: 2002+A1: 2008 Aggregates for concrete

[15] BS 812: Part 110: 1990: Testing aggregates -Methods for determination of aggregate crushing value (ACV).

[16] BS 1881: Part 102 : 2013: Testing concrete - Methods for mixing and sampling fresh concrete in the laboratory.

[17] BS 1881: Part 116: 1983: Method for Determination of Compressive Strength of Concrete Cubes. UK.

[18] Adnan, Suraya Hani, Ismail Abdul Rahman, and Y. L. Lee. "Performance of Recycled Aggregate Concrete Containing Micronized Biomass Silica." International Journal of Sustainable Construction Engineering \& Technology 1, no. 2 (2010): 1-10.

[19] Razak, H. Abdul, and H. S. Wong. "Strength estimation model for high-strength concrete incorporating metakaolin and silica fume." Cement and Concrete Research 35, no. 4 (2005): 688-695. https://doi.org/10.1016/i.cemconres.2004.05.040

[20] Standard, British. "Specification for aggregates from natural sources for concrete." London: BSI (1992): 1-9.

[21] Mehta, P. Kumar. "High-performance, high-volume fly ash concrete for sustainable development." In Proceedings of the international workshop on sustainable development and concrete technology, pp. 3-14. Ames, IA, USA: Iowa State University, 2004. 